\title{
Effect of red clover-only diets on house crickets (Acheta domesticus) growth and
}

\section{survival}

\author{
M. Vaga ${ }^{1 *}$, Å. Berggren ${ }^{2}$, T. Pauly ${ }^{3}$ and A. Jansson ${ }^{1}$ \\ ${ }^{1}$ Department of Anatomy, Physiology and Biochemistry, P.O. Box 7011, Swedish University of Agricultural Sciences, 75007 \\ Uppsala, Sweden; ${ }^{2}$ Department of Ecology, P.O. Box 7044, Swedish University of Agricultural Sciences, 75007 Uppsala, \\ Sweden; ${ }^{3}$ Department of Animal Nutrition and Management, P.O. Box 7024, Swedish University of Agricultural Sciences, \\ 75007 Uppsala, Sweden; merko.vaga@slu.se
}

Received: 6 August 2019 / Accepted: 19 December 2019

(c) 2020 Wageningen Academic Publishers

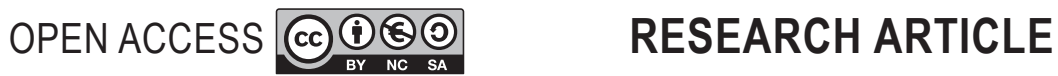

\begin{abstract}
This study evaluated the potential of red clover as a sole diet for house crickets (Acheta domesticus, AD) and the effect of ensiling or drying red clover biomass on growth, survival and water consumption of AD. Wild AD were caught near Uppsala, Sweden, and reared in a climate-controlled room under a 12-h light regime. One day-old third-generation cricket nymphs $(\mathrm{n}=2,880)$ were used in a 56-day feeding trial. The experimental diets $(\mathrm{n}=8)$ were early-cut (pre-bloom) and late-cut (late-bloom) red clover, preserved as frozen-fresh, dry-silage, haylage and hay, and a control diet. All clover diets were fed as sole diets with salt block available ad libitum in every treatment. Feed dry matter intake, feed conversion ratio (FCR, kg feed dry matter per kg weight gain), number and weight of crickets and water consumption were recorded every five days. FCR was higher for late-cut than early cut-red clover, but overall cricket weight and survival rate did not differ between cutting times $(P=0.939)$. FCR, weight and survival were not affected by forage conservation method. Total feed consumption was highest for red clover hay. Crickets fed red clover diets had lower $(P<0.01)$ weight and higher FCR than crickets fed the control diet, but their survival rate was not different from that of control crickets during the first 25 days of life. Water consumption of AD fed the control diet was about half that reported for pigs and poultry. Crickets fed on fresh red cover had lower $(P=0.04)$ water consumption compared with crickets fed dried or ensiled red clover, but ensiling did not reduce water consumption compared with hay. Red clover cannot be recommended as a sole feedstuff for AD, but early and latecut red clover had similar effects. The possibility to partly include late cut red clover in cricket diets is interesting from an ecosystem service perspective since the flowering crop will provide feed for declining populations of bees and other pollinators.
\end{abstract}

Keywords: edible insects, water intake, forages, insect nutrition, flowering crop

\section{Introduction}

Introducing insects as human food is a rising trend in Western cultures. The house cricket (Acheta domesticus, AD) is a promising species for rearing as food for human and animals, due e.g. to their high feed efficiency (Nakagaki and DeFoliart, 1991; Wilkinson, 2011) and potentially lower greenhouse gas emissions than other conventional farm animals (Oonincx et al., 2010). AD have shown a high-quality fatty acid and mineral composition (Finke, 2002; Finke and Oonincx, 2017) that meets most of the nutrient requirements of adult humans (WHO, 2007). Cricket protein is suggested to be of similar quality to soya protein (Finke et al., 1989), with an amino acid profile suitable for infants (Makkar et al., 2014). Adult AD has similar concentration of crude protein compared to beef, 600 vs $550 \mathrm{~g} / \mathrm{kg}$, lysine $35 \mathrm{vs} 45 \mathrm{~g} / \mathrm{kg}$ methionine+cystine $15 \mathrm{vs} 22 \mathrm{~g} / \mathrm{kg}$ and iron $66 \mathrm{vs} 60 \mathrm{mg} / \mathrm{kg}$ and higher fat 220 vs $40 \mathrm{~g} / \mathrm{kg}$ and energy $4,523 \mathrm{vs} 2,820 \mathrm{kcal} / \mathrm{kg}$ in dry matter (Finke et al., 2002; Makkar et al., 2014). Since AD exist naturally in Europe (https://www.gbif.org/species/1718308), 
they are likely to pose a low risk to local flora and fauna if reared in large-scale facilities.

When investing in new food production systems, it is of paramount importance not to use foodstuffs suitable for humans as animal feed or create systems that rely heavily on transportation and import of feeds (Berggren et al., 2019). As AD can utilise food by-products and forages, it is possible to rear this species in ways that do not compete with humans for food sources (Caparros Megido et al., 2016; Miech et al., 2016; Tyree et al., 1976). Field crickets (Teleogryllus testaceus) reared in captivity and fed diets including one single agricultural by-product (tops of cassava, Manihot esculenta) or weed (purple cleome, Cleome rutidosperma) displayed similar growth and feed efficiency to individuals reared on poultry feed (Miech et al., 2016). Poultry feed is commonly used in cricket rearing, but cannot be regarded as a sustainable feed, as this does not exploit AD's ability to utilise lower value organic materials (Berggren et al., 2019; Miech et al., 2016). Tyree et al. (1976) has previously shown AD to grow well on diets mainly consisting of grasses and legumes, namely lucerne (Medicago sativa). The leguminous species red clover (Trifolium pratense) is a commonly used ruminant feed in Europe. Its nutritional profile (Sheldrick et al., 1987) and the fact that $\mathrm{AD}$ is a generalist feeder indicate that clover could also be suitable for crickets. For ruminants, red clover is usually grown in mixture with grasses and therefore harvested in early bloom for optimum nutritional quality of the forage (Bosworth and Stringer, 1996). If AD can utilise red clover harvested at a late growth stage, the longer blooming period would provide feed for declining populations of bees and other pollinators (Bommarco et al., 2012) without losses in dry matter yield (Wilsie and Hollowell, 1948) as the dry matter accumulation is at its highest at 20-40\% bloom stage (Wiersma et al., 1998). In addition, use of ensiled forage, which has much higher moisture content than dry concentrate feeds, could reduce the need for providing additional drinking water for crickets. Drinking water availability has been shown to significantly influence cricket growth (McCluney and Date, 2009), but available information about the water requirement of $\mathrm{AD}$ and suitable measuring techniques are scarce (Van Huis et al., 2013).

The main aims of this study were to: (1) evaluate the potential of using early-cut and late-cut red clover as a single feed for AD; (2) evaluate the effect of red clover preservation method (hay, haylage, silage or fresh frozen) on $\mathrm{AD}$ growth and survival; and (3) estimate water consumption of AD fed fresh red clover and red clover preserved as hay, haylage or silage.

\section{Materials and methods}

\section{Feeds and crickets}

Wild house crickets (Acheta domesticus) were collected from a location near Uppsala, Sweden, and reared at Swedish University of Agricultural Sciences facilities under climate-controlled conditions. Captured adult crickets were individually grouped and reared to sufficient numbers over 3-4 generations. To prevent inbreeding, male and female breeding animals raised in different family groups were mixed for every new generation. Eggs for the experiment were collected from a total of 120 females and 120 males, by pairing one female and one male from different family groups $(\mathrm{n}=20)$ in individual plastic boxes $(\mathrm{W} 12 \times \mathrm{D} 12 \times \mathrm{H} 6$ $\mathrm{cm}$ ) that contained small containers with moist sand for egg laying. The sand containers were kept in the boxes for three days, after which the container was removed, capped and left to incubate at $32{ }^{\circ} \mathrm{C}$ for 11 days.

Red clover (Phleum pratense, cv. Yngve) was harvested from experimental fields at Röbäcksdalen research station, Umeå, Sweden $\left(63^{\circ} 35^{\prime} \mathrm{N}, 20^{\circ} 45^{\prime} \mathrm{E}\right)$. Early-cut red clover was harvested on 27 June at boot stage (before blooming occurred) and late-cut on 31 July 2017 at late flowering stage (end stage of blooming). The forage was cut by electric handheld gardening shears and then chopped with a garden shredder (Bio Master 2200; Stiga S.p.A, Castelfranco Veneto, Italy). The chopped red clover was stored fresh (frozen at $-18^{\circ} \mathrm{C}$ ) or as wilted silage, haylage or dried hay. Due to rainy weather at the harvesting times, both earlycut and late-cut red clover had to be dried indoors for silage, haylage and hay making. One portion of chopped fresh forage was packed in 1-1 plastic ziplock freezer bags and stored at $-18^{\circ} \mathrm{C}$. The rest of the chopped forage was wilted in a forced air cabinet at $50^{\circ} \mathrm{C}$ to reach the required dry matter (DM) concentration of approximately $40 \%$ for silage and $55 \%$ for haylage. The latter two fractions were ensiled without additives in 1-1 glass jars with a rubber airlock. For hay, the forage material was dried for three days in a forced air cabinet at $50{ }^{\circ} \mathrm{C}$. After 100 days, the silages were removed from the jars, packed into polythene grip-seal bags and kept frozen at $-20^{\circ} \mathrm{C}$. The aim was to have silage and haylage from both harvests, but the late-cut red clover silage and haylage ended up with similar DM content and fermentation quality $(\mathrm{pH}$, ammonia and VFA concentration), and therefore only the haylage from the late cut was used in the feeding experiment. The chemical composition of the diets is shown in Table 1. Early-cut and late-cut haylage had a similar DM content, but the $\mathrm{pH}$ was slightly lower and the ammonia nitrogen $(\mathrm{N})$ concentration higher in early-cut haylage. The early-cut red clover had higher crude protein $(\mathrm{CP})$ and soluble $\mathrm{CP}$ concentrations, but lower neutral detergent fibre (NDF) and acid detergent fibre (ADF) concentrations, than late-cut red clover. The control diet was in pelleted form (cold-pressed) and 
prepared from commercial wheat flour, oat bran, wheat bran (Lantmännen Cerealia, Stockholm, Sweden), rapeseed meal (Expro 00SF), calcium carbonate $\left(\mathrm{CaCO}_{3}\right)$ and vitaminmineral premix (Lantmännen Lantbruk, Malmö, Sweden; Table 2; Supplementary Material Table S1 and S2).

\section{Experimental design and management}

The experimental set-up comprised the control diet and seven different red clover-only diets (Table 1): (1) earlycut frozen fresh; (2) early-cut frozen silage; (3) early-cut frozen haylage; (4) early-cut hay; (5) late-cut frozen fresh; (6) late-cut frozen haylage; and (7) late-cut hay. There were six replicates per diet, with each replicate consisting of 60 nymphs from 30 different parents. This resulted in nymphs from every parent being represented in every replicate. The nymphs were collected within a day after hatching, using a handheld vacuum insect catcher (glass jar with two silicone tubes attached to the lid, one for sucking out air from the jar and the other sucks insects into the jar). The experimental period lasted 56 days, which was when the first nymphs reached adulthood. The study was terminated and all live crickets were collected and frozen on day 62 . Two nymphs from all samples were collected on day 45 for determining microbial communities and viral strains for food safety analysis (Fernandez-Cassi et al., unpublished).

The rearing facility was kept at a constant temperature of $31 \pm 1{ }^{\circ} \mathrm{C}$, relative humidity (RH) $50-60 \%$ and a $12-\mathrm{h}$ lighting regime. The crickets in each replicate were kept in transparent plastic boxes (W21 $\times$ D $17 \times \mathrm{H} 15 \mathrm{~cm})$ with a square hole $(10 \times 4 \mathrm{~cm})$ covered by stainless-steel mesh for ventilation. The boxes were placed on two different shelves, with half placed on the lower shelf and half on the higher shelf. All treatments were represented on both shelves. The temperature difference between shelves was $0.7^{\circ} \mathrm{C}$. Water was provided in $10 \mathrm{~cm}$ long plastic vials $(\varnothing 14 \mathrm{~mm})$ with cotton at the opening and the vials were changed every
15 days. Feed was provided in plastic petri dishes during the first 30 days and thereafter in conical feeders made of galvanised steel netting (mesh size $3 \mathrm{~mm}$ ) attached to petri dishes. The conical feeders were evaluated beforehand to ensure that they allowed free access to the feed from below (through the netting). Plastic straws ( $\mathrm{L} \sim 5 \mathrm{~cm})$ and tubes made of black polyethylene water piping (ø $25 \mathrm{~mm}$ ) (Vaga et al., 2018) were placed in the boxes to provide hiding places and to allow the crickets to express their natural hiding behaviour. Feed refusals were removed and new feed provided every five days. Natural mineral salt blocks (Albert Kerbl GmbH, Buchbach, Germany) were freely available for all crickets.

\section{Chemical analysis}

Dry matter concentration was determined in feeds before the start of the experiment and in feed refusals. Feed refusals from replicates were pooled for chemical analysis. Preliminary DM concentration in fresh forage, silage and haylage samples was determined by drying at $60^{\circ} \mathrm{C}$ for $24 \mathrm{~h}$ and corrected for volatile losses. Final DM concentration

\section{Table 2. Ingredients of the control diet.}

$\begin{array}{lc}\text { Item } & \text { g/kg dry matter } \\ & \\ \text { Wheat bran } & 308 \\ \text { Oats bran } & 296 \\ \text { Wheat meal } & 224 \\ \text { Rapeseed meal }^{1} & 150 \\ \mathrm{CaCO}_{3} & 17.9 \\ \text { Premix }^{2} & 4.0 \\ & \\ { }^{1} \text { Expro 00SF. } & \\ { }^{2} \text { Trace elements + vitamin premix (Lantmännen Lantbruk, Malmö, Sweden). }\end{array}$

Table 1. Chemical composition of the control diet and of the early-cut (EC) and late-cut (LC) red clover diets. ${ }^{1}$

\begin{tabular}{|c|c|c|c|c|c|c|c|c|c|}
\hline \multirow[b]{2}{*}{ Item } & \multirow[t]{2}{*}{$\mathrm{DM}(\mathrm{g} / \mathrm{kg})$} & \multicolumn{5}{|c|}{ g/kg DM } & \multirow{2}{*}{$\begin{array}{l}\text { Soluble } N \\
(\mathrm{~g} / \mathrm{kg} \mathrm{N})\end{array}$} & \multirow{2}{*}{$\begin{array}{l}\text { Ammonia N } \\
(\mathrm{mg} / \mathrm{l})\end{array}$} & \multirow[t]{2}{*}{$\mathrm{pH}$} \\
\hline & & Ash & $\mathrm{CP}$ & NDF & ADF & Starch & & & \\
\hline Control diet & 962 & 59 & 192 & 208 & 80 & 376 & 564 & NA & NA \\
\hline EC fresh frozen & 103 & 120 & 217 & 313 & 200 & 20 & 581 & 14.1 & 5.6 \\
\hline EC silage & 336 & 128 & 214 & 342 & 219 & 19 & 848 & 268 & 4.25 \\
\hline EC haylage & 525 & 131 & 218 & 334 & 225 & 20 & 731 & 234 & 4.79 \\
\hline EC hay & 939 & 123 & 199 & 332 & 227 & 19 & 569 & NA & $\mathrm{NA}$ \\
\hline LC fresh frozen & 137 & 91 & 128 & 476 & 342 & 21 & 406 & 25.5 & 5.69 \\
\hline LC haylage & 547 & 94 & 143 & 491 & 335 & 20 & 396 & 224 & 5.13 \\
\hline LC hay & 946 & 88 & 130 & 489 & 352 & 22 & 338 & NA & NA \\
\hline
\end{tabular}

${ }^{1} \mathrm{DM}=$ dry matter, $\mathrm{CP}=$ crude protein, $\mathrm{NDF}=$ neutral detergent fibre, $\mathrm{ADF}=$ acid detergent fibre. 
was determined for all feeds by drying at $105^{\circ} \mathrm{C}$ for $16 \mathrm{~h}$ and ash concentration was determined after incinerating samples at $500{ }^{\circ} \mathrm{C}$ for $4 \mathrm{~h}$ (AOAC, 1990). All feeds were analysed for $\mathrm{CP}$ and buffer soluble $\mathrm{N}$ fractions of $\mathrm{CP}$ (soluble CP) with Kjeldahl nitrogen methods (Nordic Committee of Food Analysis, 1979) using a 2020 Digestor and a 2400 Kjeltec Analyser Unit (FOSS Analytical A/S, Hilleröd, Denmark). The feeds were analysed for NDF and ADF with heat stable $\alpha$-amylase and sodium sulphite (Mertens et al., 2002), using the filter bag technique in an ANKOM200 Fiber Analyzer (Ankom Technology Corp., Macedon, NY, USA). The frozen silage and fresh forage samples were thawed and pressed, and the $\mathrm{pH}$ in the liquid was measured with a calibrated $\mathrm{pH}$ meter (Metrohm, Herisau, Switzerland) and further analysed for volatile fatty acids and lactic acid (Ericson and André, 2010). Ammonium-N content in silage was determined by direct distillation after adding $\mathrm{MgO}$, using a Kjeltec 2100 Distillation Unit (Foss Analytical A/S).

\section{Calculations and statistical analysis}

The crickets were weighed inside their box after removing all other items (feeder, water tube, feed, frass) from the box. The weight of the box was deducted and the total weight of crickets was divided by the number of crickets to get the average weight of individual crickets. Feed DM consumption was calculated as the difference between amount of feed DM administered and refusal DM after every five days. The late-cut red clover hay had a high proportion of fine particles that were difficult to completely separate from faeces, resulting in small losses of feed, and therefore the DM consumption values for this feed are most likely overestimates. Natural logarithm of weekly weight gain was plotted against time (days) and then the slope multiplied by $100 \%$ to calculate crickets growth rate as percentages per day. Feed conversion ratio (FCR) was calculated as g feed DM consumed per g weight gain. Total mean feed DM consumption was divided by mean cricket weight at day 56 (day 45 for early-cut fresh red clover). The FCR for each five-day period was calculated only for the first 45 days for red clover treatments, due to low survival and growth after this stage.

Water consumption of the crickets was calculated by measuring the total water disappearance from the water vials in the treatment boxes and subtracting the water lost by evaporation. The water vials were weighed every five days, at the same time as the feed and the crickets. As evaporation controls, eight water vials were placed separately in plastic boxes without crickets and these boxes were placed between the treatment boxes. The evaporation control vials were weighed daily and changed every 15 days, at the same time as the water vials were changed in the cricket boxes. The daily reduction in water from the evaporation control vials was used to estimate normal evaporation rate. The coefficient of variation $(\mathrm{CV})$ of evaporation rate from control water tubes measured daily was $18.7 \%$. All weighing (feed, water, cricket boxes, etc.) was performed on the same balance $\left( \pm 2 \mathrm{mg}\right.$; OHAUS ${ }^{\mathrm{rm}}$ Explorer $^{\text {ts }}$; Thermo Fisher Scientific Inc., Gothenburg, Sweden).

The data were analysed by ANOVA, using the MIXED procedure in SAS (version 9.4, SAS Institute Inc., Cary, $\mathrm{NC}$, USA). Least square means of survival rate, weight, feed and water consumption and FCR between diets at day 45 and 62 were estimated using the statistical model:

$Y_{i j k}=\mu+F_{i}+s_{j}+d_{k}+e_{i j k}$

where $Y_{i j k}$ is a dependent variable and $\mu$ is the overall mean of observations, $F_{i}$ is the effect of diet, $s_{j}$ is the random effect of box location on the shelf (location of the cricket box in the room: lower or upper shelf), $d_{k}$ is the random effect of sampling day and $\mathrm{e}_{\mathrm{ijk}}$ is the random residual error. Comparisons of red clover cutting times and treatment effects on survival rate, cricket weight, feed and water consumption and FCR were made using the statistical model:

$Y_{i j k}=\mu+C_{i}+T_{j}+C_{i} T_{j}+s_{k}+e_{i j k}$

where $Y_{\mathrm{ijk}}$ is a dependent variable and $\mu$ is the overall mean of observations, $C_{i}$ is the effect of cut, $T_{j}$ is the effect of preservation method of feed (fresh, silage, haylage or hay), $\mathrm{C}_{\mathrm{i}} \mathrm{T}_{\mathrm{j}}$ is the interaction effect of cut and treatment method, $s_{k}$ is the random effect of box location on the shelf and $e_{i j k}$ is the random residual error. The model was corrected for multiple comparisons by Tukey-Kramer adjustment. The overall effects of feed cutting time and conservation method on survival rate and weight gain were compared by the same statistical model, with time points treated as repeated measurements. Least square means of CP, sCP, NDF and $\mathrm{ADF}$ concentrations in feed refusals were compared against concentrations in original diets (day 0) using ANOVA and Tukey contrast (models included day and diet). Differences were declared statistically significant at $P \leq 0.05$.

\section{Results}

\section{Feed intake and refusals}

Daily DM intake per cricket was not different between red clover diets during the first 40 days (Figure 1). However, both harvesting time and conservation method had an effect on total feed DM intake.

By day 56, total DM intake was lower $(P<0.001)$ with earlycut red clover than with late-cut, and it was lower $(P=0.001)$ with silage than with hay (Table 3$)$. For the control diet, daily DM intake was consistently $(P<0.001)$ higher than for the other diets from day 9. During the first 20 days, the 


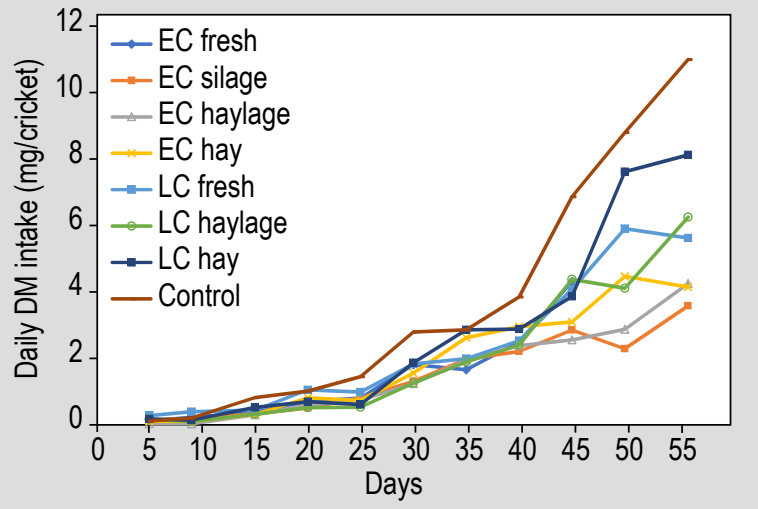

Figure 1. Average daily dry matter (DM) intake of crickets fed a control diet, early-cut red clover (EC) and late-cut red clover (LC) and red clover diets conserved as fresh (frozen), silage, haylage or hay.

five-day FCR (g feed DM/g weight gain) was on average $1.9(\mathrm{SD}=1.11)$, with no differences between red clover diets (Figure 2). After day 20, the FCR increased rapidly to an average of $5.5(\mathrm{SD}=2.79)$ for all red clover diets. The FCR for the control diet was on average $0.9(\mathrm{SD}=0.13)$ during the first 25 days, but increased to on average $1.8(\mathrm{SD}=0.27)$ from day 30 to day 56. Overall, total FCR for red clover forage was 4.6 by day 56 , whereas with the control diet it was 1.5 (Table 3).

Chemical concentration of diets and feed refusals was measured in pooled samples and therefore statistical comparison was not performed for individual diets, but only between diets and refusals (Table 4). On average over all diets, the feed refusals from first 20 days and 20-45 days had similar CP concentration as original diets (day 0$)$. Soluble $\mathrm{CP}$ concentration was on average $13 \%$ lower $(P=0.001)$ in feed refusals compared to original diets. The NDF and ADF concentrations in feed refusals were on average $31 \%$ and

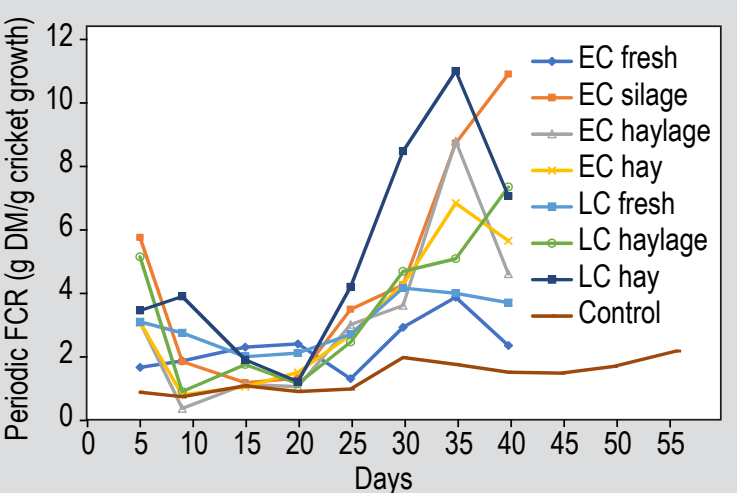

Figure 2. Average feed conversion ratio (FCR; $g$ feed dry matter (DM) per g cricket liveweight produced) for consecutive fiveday periods in crickets fed a control diet, early-cut (EC) and late-cut (LC) red clover-only diets conserved as fresh (frozen), silage, haylage or hay.

$22 \%$ greater $(P<0.001)$, respectively, than in the original diets. On three occasions, visible mould was observed on feed refusals on early cut fresh red clover samples.

\section{Growth}

Already from day 9 , the average cricket weight was higher $(P<0.001)$ in the control group than in the red clover diet groups (Figure 3). At day 56 the average weight of control crickets was $145 \mathrm{mg}(\mathrm{SD}=55)$ whereas the average weight of crickets fed red clover diets was $29 \mathrm{mg}(\mathrm{SD}=16)$, with crickets fed late-cut fresh red clover being heavier (40 mg; $P<0.001)$ than crickets fed the other red clover diets. During the first 20 days, the average growth rate of crickets fed red clover diets remained steady $(\mathrm{R}=0.99)$ at $11 \% /$ day ( $\mathrm{SD}=7.0)$, compared with $14 \%$ /day with the control diet (Figure 3). However, after 20 days the average daily growth rate decreased to a steady $(R=0.99)$ average of $4.5 \%$ /day

Table 3. Total dry matter intake (DMI, $\mathrm{mg} / \mathrm{cricket}$ ), weight gain (WG, $\mathrm{mg} / \mathrm{cricket}$ ) and feed conversion ratio (FCR, $\mathrm{g} / \mathrm{g}$ ) in Acheta domesticus fed early-cut or late-cut fresh or conserved red clover-only diets for 56 days.

\begin{tabular}{|c|c|c|c|c|c|c|c|c|c|c|c|c|c|}
\hline \multirow[t]{2}{*}{ Item } & \multirow[t]{2}{*}{ Control } & \multicolumn{4}{|c|}{ Early-cut } & \multicolumn{3}{|c|}{ Late-cut } & \multirow[t]{2}{*}{ SEM $^{1}$} & \multicolumn{4}{|l|}{$P$-value ${ }^{2}$} \\
\hline & & Fresh & Silage & Haylage & Hay & Fresh & Haylage & Hay & & C vs RC & EC vs LC & $\begin{array}{l}\text { Silage } \\
\text { vs hay }\end{array}$ & $\begin{array}{l}\text { Haylage } \\
\text { vs hay }\end{array}$ \\
\hline DMI (mg) & 219 & $\mathrm{NA}^{3}$ & 77 & 84 & 100 & 135 & 117 & 164 & 19.5 & $<0.001$ & $<0.001$ & 0.001 & 0.016 \\
\hline WG (mg) & 145 & NA & 24 & 30 & 31 & 40 & 22 & 25 & 9.7 & $<0.001$ & 0.939 & 0.722 & 0.839 \\
\hline FCR $(\mathrm{g} / \mathrm{g})$ & 1.5 & NA & 4.2 & 3.1 & 4.7 & 3.5 & 6.1 & 6.1 & 0.77 & 0.001 & 0.013 & 0.241 & 0.373 \\
\hline
\end{tabular}


Table 4. Mean concentration of crude protein (CP), soluble crude protein (SCP), neutral detergent fibre (NDF) and acid detergent fibre (ADF) in diets (day 0 ) and in feed refusals on day 20 and 45. Values presented are $\mathrm{g} / \mathrm{kg}$ dry matter.

\begin{tabular}{|c|c|c|c|c|c|}
\hline \multirow[t]{2}{*}{ Item } & \multirow[t]{2}{*}{ Diets } & \multicolumn{2}{|c|}{ Feed refusals } & \multirow[t]{2}{*}{ SEM $^{1}$} & \multirow{2}{*}{$\begin{array}{l}P \text {-value }{ }^{2} \\
\text { Diet vs } \\
\text { refusals }\end{array}$} \\
\hline & & Day 20 & Day 45 & & \\
\hline Crude protein $(\mathrm{CP})$ & 180 & 178 & 182 & 11.3 & 0.991 \\
\hline Soluble CP & 554 & 479 & 482 & 32.5 & 0.001 \\
\hline NDF & 373 & 481 & 495 & 20.2 & $<0.001$ \\
\hline ADF & 248 & 298 & 308 & 23.6 & $<0.001$ \\
\hline
\end{tabular}

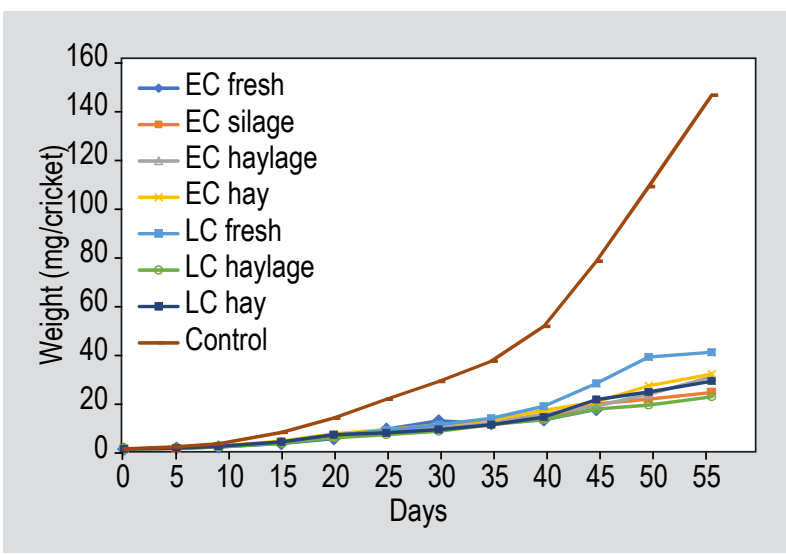

Figure 3. Weight $(\mathrm{mg})$ of crickets fed a control diet, early-cut (EC) and late-cut (LC) red clover-only diets conserved as fresh (frozen), silage, haylage or hay.

$(\mathrm{SD}=0.55)$ with red clover diets and 6.5\%/day growth with the control diet until day 56 . Only in the control group some crickets ( 4\%) had reached maturity by day 56 .

\section{Survival}

Mortality was highest in the beginning of the experiment, with $17-41 \%$ of the 60 nymphs per sample lost within the first five days (Figure 4). During the first five days, crickets fed early-cut fresh red clover had a lower survival rate $(P<0.001)$, and crickets fed early-cut silage and control diet had a higher survival rate $(P<0.05)$, than crickets fed the other red clover diets.

Between days 5 and 30 , the survival rate remained at $83 \%$ per five-day period, with no differences between diets $(P>0.05)$. From day 30, the survival rate in all red clover diets decreased to $49-76 \%$ per five-day period. The early-cut fresh diet was

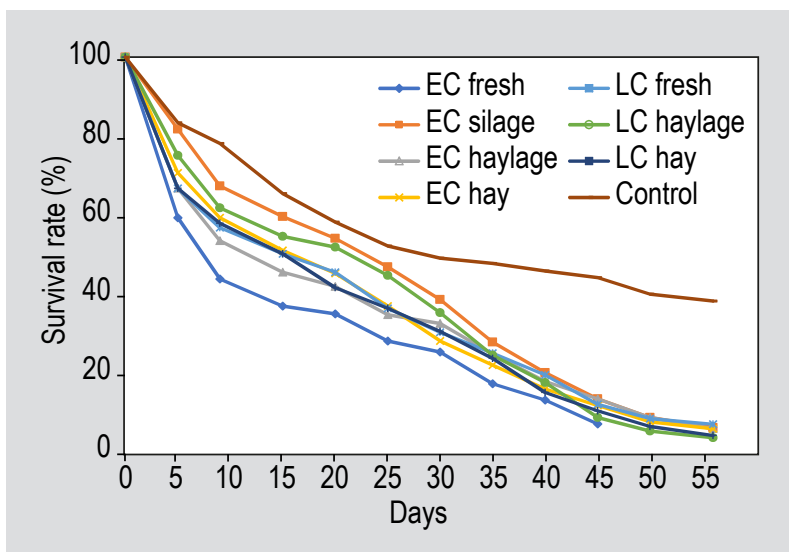

Figure 4. Survival rate (\%) of crickets fed a control diet and early-cut (EC) and late-cut (LC) red clover diets conserved as fresh (frozen), silage, haylage or hay.

terminated at day 45 , when only $4 \pm 3$ crickets per replicate were still alive. On average, only 2-4 crickets per replicate fed the red clover-only diets (not counting the two crickets per replicate removed on day 45) survived until day 56. In comparison, the survival rate of crickets in the control group was on average $92 \%$ ( $\mathrm{SD}=5.1$ ) for every five-day period during the whole study and an average of $22 \pm 2$ crickets remained alive on day 56 . No difference $(P=0.552)$ was found in average survival rates, calculated for every five-day period, between early-cut $(77 \%, \mathrm{SE}=3.8)$ and late-cut red clover $(76 \%)$, or between different conservation methods $(P=0.57)$.

\section{Water consumption}

Daily water consumption per cricket was lower $(P=0.012)$ with fresh red clover compared with hay (Figure 5). On average during the first 45 days, the daily water consumption (per g cricket liveweight) with red clover diets was $0.72 \mathrm{ml} / \mathrm{g}$ $(\mathrm{SD}=0.59)$.

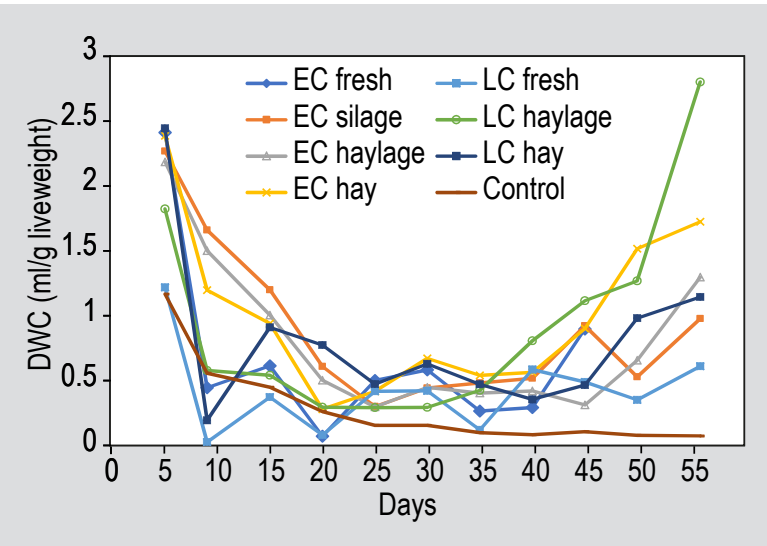

Figure 5. Daily water consumption (DWC, $\mathrm{ml}$ ) per g liveweight by crickets fed a control diet and early-cut (EC) and late-cut (LC) red clover-only diets conserved as fresh (frozen), silage, haylage or hay. 
However, crickets fed late-cut fresh red clover and control diet had lower $(P<0.05)$ daily water consumption compared with those fed the other red clover diets $(0.47$ and $0.41 \mathrm{ml} / \mathrm{g}$ liveweight, $\mathrm{SD}=0.35$, respectively). In total, by day 56 , the crickets fed the red clover-only diets consumed on average $20 \mathrm{ml}(\mathrm{SD}=9.3)$ and crickets fed the control diet $1.76 \mathrm{ml}$ $(\mathrm{SD}=0.37)$ of water per $\mathrm{g}$ liveweight (Table 5). Total water consumption ( $\mathrm{ml} / \mathrm{g}$ liveweight) by AD was not different between early-cut and late-cut red clover $(P>0.05)$.

\section{Discussion}

\section{Red clover as feed for $A D$}

The main aim of this study was to evaluate the potential of red clover-only diets to AD. Despite high feed intake and relatively high CP concentration (>200 g/kg DM) in earlycut red clover, the growth of $\mathrm{AD}$ on all red clover diets was lower than on the control diet. Similarly, Tyree et al. (1976) found that $\mathrm{AD}$ fed timothy or alfalfa as sole feeds for 28 days had lower survival rate and lower average weight than crickets fed a mixed diet. On the other hand, Miech et al. (2016) showed that cassava tops and purple cleome (Cleome rutidosperma) can work as sole feed for field crickets. For the first 25 days of life only small differences in survival rate

Table 5. Total water consumption per cricket (ml/g liveweight) and water-consumption-to-feed ratio (W:F; feed dry matter) in Acheta domesticus fed early-cut (EC) and late-cut (LC) fresh or conserved red clover-only diets for 56 days. Means \pm standard deviation.

\begin{tabular}{|c|c|c|}
\hline Diet & Water (ml/g liveweight) & W:F ratio \\
\hline Control & $1.8 \pm 0.4$ & $1.3 \pm 0.3$ \\
\hline EC fresh ${ }^{1}$ & NA & NA \\
\hline EC silage & $19.5 \pm 7.6$ & $5.1 \pm 2.3$ \\
\hline EC haylage & $15.7 \pm 15.3$ & $3.4 \pm 2.3$ \\
\hline EC hay & $29.1 \pm 25.2$ & $6.3 \pm 3.0$ \\
\hline LC fresh & $7.6 \pm 3.0$ & $2.6 \pm 1.6$ \\
\hline LC haylage & $33.6 \pm 26.8$ & $5.7 \pm 3.1$ \\
\hline LC hay & $20.3 \pm 18.2$ & $2.5 \pm 1.3$ \\
\hline SEM $^{2}$ & 6.88 & 0.86 \\
\hline \multicolumn{3}{|l|}{$P$-value ${ }^{3}$} \\
\hline Control vs red clover & 0.010 & 0.002 \\
\hline Early vs late cut & 0.295 & 0.377 \\
\hline Fresh vs haylage & 0.041 & 0.052 \\
\hline Fresh vs hay & 0.046 & 0.074 \\
\hline Silage vs hay & 0.418 & 0.431 \\
\hline \multicolumn{3}{|l|}{${ }^{1}$ Data not available. } \\
\hline \multicolumn{3}{|l|}{2 Standard error of mean. } \\
\hline \multicolumn{3}{|c|}{$\begin{array}{l}{ }^{3} \text { Significance of effect between control diet and red clover diets due to harves } \\
\text { time (early vs late cut) or conservation method (fresh vs haylage; fresh vs } \\
\text { hay; silage vs hay). }\end{array}$} \\
\hline
\end{tabular}

were observed between the control diet and most of the red clover diets (Figure 1). This indicates that red clover could be included as a feed ingredient in the early growth period. The exact growth-limiting factors in red clover as a feed for $\mathrm{AD}$ require further study, but Tyree et al. (1976) found that even $10 \%$ inclusion of concentrate feed in a forage-based diet was sufficient to give same or even higher survival rate and growth as in AD fed a concentrate only diet.

Although FCR was lower for early-cut red clover than for late-cut, there were no significant differences in growth and survival between the early-cut and late-cut red clover diets. This shows that red clover used for feeding AD can be harvested after the flowering stage. The CP concentration was significantly lower in late-cut red clover than in earlycut (Table 1), but was still above $13 \%$ of DM. McFarlane (1964) found that growth of AD was not affected by CP level with diets containing $10-50 \%$ CP. This adds an additional value to red clover as a feed crop, as the flowering plants can also provide feed for pollinators. The declining use and early harvesting of red clover in modern agriculture is contributing to loss of flowering habitats for insects (Bommarco et al., 2012; Gärdenfors, 2010). It is therefore important to utilise any opportunity for late harvesting in feed production. From an animal production perspective, for $\mathrm{AD}$ it seems a viable option as there are benefits (or no negative effects) of late-harvested feedstuffs for animal growth, health or survival. Later harvesting generally also means higher DM yields and lower risk of rainfall during harvest in Scandinavia (www.smhi.se; www.yr.no).

\section{Effect of ensiling red clover}

Ensiling is the dominant method for preserving forages over winter for animal feed in most parts of the world. However, production of organic and volatile fatty acids during the fermentation process in ensiling decreases the $\mathrm{pH}$ and can change the palatability of plant material (Chamberlain, 1987). This may explain the lower feed intake by AD fed silage and haylage compared with individuals fed hay and fresh diets (Table 3). Despite the lower DM intake, weight gain was not significantly lower with silage and haylage, leading to similar or even lower FCR than for red clover hay. In addition, silage and late-cut haylage gave the highest AD survival rate of all the red clover diets during the early growth stage of AD (Figure 4). Degradation of material during silage fermentation could make some nutrients more easily digestible for the crickets. Ensiled forage has higher concentration of soluble $\mathrm{N}$, including free amino acids, peptides and ammonia-N (Purwin et al., 2015), microbial $\mathrm{N}$ and yeast (Elferink et al., 2000; Rooke and Hatfield, 2003) than dried red clover hay. This indicates that fermented silage, and possibly even highly degraded silage, could be utilised as feed for AD. However, in this study there was no apparent benefit of conservation methods with predigestion (i.e. haylage or silage) on feed intake or FCR. 
The AD in this study seemed to eat selectively, since the proportion of soluble CP was lower and NDF and ADF were higher in feed refusals than in the original diet (Table 4). This means that softer and less fibrous parts (leaves) of the red clover were eaten to a greater extent than stems. Such selective eating behaviour would result in feeding management issues, with the higher-quality parts of the plants consumed first and the rest left as waste. In cattle and other domestic animals, total mixed ration feeding is practised partly to reduce selective feeding (Nielsen et al., 2016). This method could also be useful in feeding crickets, but would require relatively fine milling and possibly pelleting of the feed mixture. These procedures might also make nutrients in red clover stems more accessible and improve utilisation. Despite the higher concentration of soluble $\mathrm{N}$ in silage than in the other diets (Table 1), the soluble $\mathrm{N}$ concentration in silage refusals did not differ from that in the original diet (Table 4). This may indicate better availability of non-soluble $\mathrm{N}$ fractions in fermented feed or possible continued degradation of silage proteins after exposure to air (Pahlow et al., 2003). Higher availability of non-soluble nutrients in silage could therefore reduce selective feeding and feed waste compared with dried forages.

\section{Feed conversion ratio}

Due to low growth and survival of AD fed on red clover, the high $(>5)$ final FCR values cannot be compared with those obtained for the control diet or to previous studies (Table 3). Importantly however, the FCR of 1.5 in crickets fed the control diet is comparable to that in other livestock such as salmon, poultry and pigs (FCR 1.3, 1.8 and 3.0, respectively) (Smil, 2002; Tacon and Metian, 2008) and shows that AD can be reared with the same efficiency. A slightly higher FCR of insects compared with other livestock can be environmentally and economically sustainable if it is achieved by feeding ecologically beneficial and lowcost feeds (Collavo et al., 2015; Lundy and Parrella, 2015), instead of using resources suitable for human food. It is possible that $\mathrm{AD}$ can efficiently utilise a wide range of organic materials, including weeds and food waste (Makkar et al., 2014; Miech et al., 2016). During the first 25 days of cricket development in our study, the FCR for red clover diets (2.08) was around twice as high as for the control diet (0.95). This supports the use of red clover as a dietary ingredient for crickets, but detailed studies are needed to understand the right the level of supplementation. While FCR is good in comparing different diets, it does not inform us about the sustainability of the feed. Other aspects such as animal nutritional values, water consumption (Halloran et al., 2017) and ethical questions around mortality rates are all highly relevant for cricket rearing. Low FCR can sometimes be found with diets that have unacceptably high mortality rates (Miech et al., 2016). The calculations in our study did not take into account he dietary contribution resulting cannibalism. Cannibalism is unlikely to have a large effect since there were no significant differences in survival rate between red clover and control diet during the first 30 days. Dietary ingredients and diet chemical composition have strong effect on $\mathrm{AD}$ development, yet these effects are poorly studied compared to other livestock. Lundy and Parrella (2015) found strong correlation ( $\mathrm{R}=0.96)$ between AD growth and feed quality (based on protein and fibre ratio and fat content), but in other studies correlations between diet composition and crickets' growth or survival has not been clearly identified (Miech et al., 2016; Oonincx et al., 2015; Orinda, 2018). Besides two studies where sustainable cricket growth was achieved on plant-only diets (Caparros Megido et al., 2016; Miech et al., 2016), best growth results have been seen with broiler feed, food waste or mixed diets containing animal proteins (Lundy and Parrella, 2015; Nakagaki and DeFoliart, 1991; Patton, 1978). In our study the control diet was cereal based and without any animal proteins. This may explain the slightly longer development and lower final cricket weight in our study compared to the previous studies. In addition, the $\mathrm{AD}$ individuals used in our study reached a similar average weight as in the study by Lundy and Parrella (2015), but had a longer development time. The longer development time and lower final weight compared with many other studies (Oonincx et al., 2015; Orinda, 2018) can also be partly explained by that crickets used in our study were wild crickets not yet adapted for controlled climate and feeding regime conditions. After additional generations in captivity and selective breeding, the FCR in the wild Swedish AD would probably decline.

\section{Mortality}

The seemingly high initial mortality rate of crickets in this study (17-41\%) is similar to previous studies. The first days after hatching are usually associated with high mortality, e.g. rates exceeding 20\% during the first 5-7 days are common (Collavo et al., 2005; Miech et al., 2016; Morales-Ramos et al., 2018). This should be taken into account when planning studies involving newly hatched insects. The reason for the low survival on early-cut fresh red clover in the present study is unclear. Feed intake was comparatively high on this diet, so nutrient intake was probably not the limiting factor. One reason might be altered microbial growth on the thawed fresh frozen material. Bacterial and fungal growth occurs fast in moist forages, especially in humid and warm conditions, and can be harmful to the animals (McDonald, 2011) This could explain the visible mould detected on some of the feed refusal samples and the low survival rate of crickets on early cut fresh red clover. However, the survival rate on late-cut fresh red clover was not significantly different from other red clover diets. Early-cut red clover has higher polyphenol oxidase activity than in late cut red clover and in other legumes (Lee et al., 2009) which may reduce digestibility and affect survival 
rate of crickets. AD fed on lucerne diets (feed with a low oxidase activity) have been shown to have higher survival rates than in our study (Jones et al., 1995; Tyree et al., 1976).

The sudden decline in survival rate and in weight gain with all red clover diets after day 25 may indicate changes in metabolism or nutrient requirements of $\mathrm{AD}$ at certain development stages, and an inability of red clover to fulfil these requirements. Despite the smaller size of our crickets, the changes in growth and survival rates correspond well with findings by Patton (1978), who observed the highest growth rate in $\mathrm{AD}$ at 25-32 days and suggested that the species has the highest nutritional requirements during this period. He therefore emphasises the need to provide high quality nutritional diets for this growth period. Since there were no differences in cricket mortality between early-cut and late-cut red clover diets, it is likely that the $\mathrm{CP}$ and NDF concentrations were not limiting factors. Miech et al. (2016) compared a variety of plants and food industry by-products as feed for field crickets and found no general correlation between main feed components such as CP, crude fat and crude fibre and cricket survival rate or weight gain. Simpson et al. (2006) found that mass-moving Mormon crickets (Anabrus simplex) clearly preferred and spent more time eating protein diets $(42 \%$ and $21 \% \mathrm{CP})$ than protein-free carbohydrate diets. In contrast, Orinda (2018) found that AD and Gryllus bimaculatus consumed five times more rice bran with a lower CP content (19\%) than blood meal with high CP (87\%) when given a free choice of these two diets. In this study we found no dead crickets in the boxes, but we were unable to determine whether the dead crickets were cannibalised after their death or whether predation occurred. To understand how diet effects the frequency of cannibalism in cricket rearing situations, more studies are required.

\section{Drinking water requirements}

The water consumption of crickets in the control group was similar to that reported in earlier studies on AD (Roe et al., 1980; Woodring et al., 1977), and based on body weight, comparable to that of growing pigs and broiler chickens (NRC, 1998; Williams et al., 2013). Based on NRC (1998), growing pigs (30-40 kg bodyweight) require approximately $100 \mathrm{ml}$ water per $\mathrm{kg}$ bodyweight daily and older pigs require about $60-80 \mathrm{ml} / \mathrm{kg}$ bodyweight. In AD fed the control diet, the calculated equivalent daily water consumption was on average $305 \mathrm{ml} / \mathrm{kg}$ bodyweight during the first 30 days and $73 \mathrm{ml} / \mathrm{kg}$ from 30-56 days of age. However, the water consumed to produce $1 \mathrm{~kg}$ of AD (liveweight) was $1.84 \mathrm{l}$ (56 days), whereas pigs reared for 22 weeks, to about $110 \mathrm{~kg}$, would require approximately 4.61 to produce $1 \mathrm{~kg}$ liveweight (total of 500 l). When we compared water consumption in $\mathrm{AD}$ and broilers, we used water to feed DM intake ratio (W:F; Table 5). For broilers, the W:F ratio is about 1.902.02 (Williams et al., 2013) whereas for AD reared on our control diet it was $1.12(\mathrm{SD}=0.323)$. These results confirm that water consumption of $\mathrm{AD}$ is low compared with that of conventional livestock (Van Huis et al., 2013). However, with lower feed quality and increased growing time, the need for water would increase. In addition, the total use of water for rearing would increase if the crickets' need for high relative humidity $(\sim 50 \%)$ is taken into account (Clifford and Woodring, 1990).

The method we used to measure water consumption proved useful to estimate drinking water requirement, but it was not sufficiently precise $(\mathrm{CV}=19 \%)$ to detect small differences between diets. The crickets were expected to consume less water when fed fresh or ensiled forage compared with hay and haylage, but water use was only significantly lower with fresh forage compared with hay. However, subjectively the water consumption with fresh forages and silages was noticeably lower during the first 1-2 days after feeding, when the feed was still wet or moist. This indicates that when moist feed is offered in small quantities and in warm conditions, an external water source might still be needed.

\section{Conclusions}

The results of this study indicate that red clover as a sole feedstuff is not suitable for rearing house crickets, although only small reductions in survival and growth were observed during the first 20 days. This indicates that red clover can have potential as a feed ingredient in the early growth period. There was no effect of cutting time of red clover on growth and mortality of house crickets, so late-cut (post flowering) red clover can be used in cricket diet. Harvesting feed material late would provide a flowering resource for pollinators and improve biodiversity in the agricultural landscape. Cricket growth and mortality were not negatively affected by ensiling the red clover. This means that there is no need to change existing harvesting and conservation methods such as ensiling or drying. House crickets seem to have a lower water requirement than pigs and poultry, and feeding moist forages can further reduce (but not eliminate) water consumption compared with dry feeds like hay and haylage.

\section{Acknowledgements}

The authors thank the Swedish research council Formas for funding this project (no. 2016-00361).

\section{Supplementary material}

Supplementary material can be found online at https://doi. org/10.3920/JIFF2019.0038.

Table S1. Detailed chemical composition of the control feed. 
Table S2. Chemical composition of Premix 'Vaga' (Lantmännen, Lantbruk, Malmö, Sweden).

\section{References}

Association of Official Analytical Chemists (AOAC), 1990. Official methods of analysis (15 $5^{\text {th }} \mathrm{Ed}$.). AOAC, Arlington, VA, USA.

Berggren, Å., Jansson, A. and Low, M., 2019. Approaching ecological sustainability in the emerging insects-as-food industry. Trends in Ecology and Evolution 34: 132-138. https://doi.org/10.1016/j. tree.2018.11.005

Bommarco, R., Lundin, O., Smith, H.G. and Rundlöf, M., 2012. Drastic historic shifts in bumble-bee community composition in Sweden. Proceedings of the Royal Society B: Biological Sciences 279: 309315. https://doi.org/10.1098/rspb.2011.0647

Bosworth, S.C. and William, C. and Stringer, W.C., 1996. Cutting management of alfalfa, red clover, and birdsfoot trefoil. Agronomy Facts no. 7. College of Agricultural Sciences, The Pennsylvania State University, State College, PA, USA.

Caparros Megido, R., Alabi, T., Nieus, C., Blecker, C., Danthine, S., Bogaert, J., Haubruge, É. and Francis, F., 2016. Optimisation of a cheap and residential small-scale production of edible crickets with local by-products as an alternative protein-rich human food source in Ratanakiri Province, Cambodia. Journal of the Science of Food and Agriculture 96: 627-632. https://doi.org/10.1002/jsfa.7133

Chamberlain, D.G., 1987. The silage fermentation in relation to the utilization of nutrients in the rumen. Process Biochemistry 22: 60-63.

Clifford, C.W. and Woodring, J.P., 1990. Methods for rearing the house cricket, Acheta domesticus (L.), along with baseline values for feeding rates, growth rates, development times, and blood composition. Journal of Applied Entomology 109: 1-14. https:// doi.org/10.1111/j.1439-0418.1990.tb00012.x

Collavo, A., Glew, R.H., Huang, Y.S., Chuang, L.T., Bosse, R. and Paoletti, M.G., 2005. House cricket small-scale farming. In: Paoletti, M.G. (ed.) Ecological implications of minilivestock: potential of insects, rodents, frogs and snails. CRC Press, Boca Raton, FL, USA, pp. 519-544.

Elferink, S.J.W.H.O., Driehuis, F., Gottschal, J.C. and Spoelstra, S.F., 2000. Silage fermentation processes and their manipulation. In: ' $t$ Mannetje, L. (ed.) Proceedings of the FAO electronic conference on tropical silage. September 1 - December 15, 1999, FAO, Rome, Italy, pp. 17-30. http://www.Fao.Org/Docrep/005/X8486E/X8486E09.htm

Ericson, B. and André, J., 2010. HPLC - applications for agricultural and animal science. In: Proceedings of the $1^{\text {st }}$ Nordic Feed Science Conference. June 22-23, 2010, Uppsala, Sweden, pp. 23-26.

Finke, M.D., DeFoliart, G.R., and Benevenga, N.J. 1989. Use of a fourparameter logistic model to evaluate the quality of the protein from three insect species when fed to rats. Journal of Nutrition 119: 864-871. https://doi.org/10.1093/jn/119.6.864

Finke, M.D. and Oonincx, D.G.A.B., 2017. Insects and nutrients. In: Van Huis, A. and Tomberlin, J.K. (eds.) Insects as food and feed: from production to consumption. Wageningen Academic Publishers, Wageningen, the Netherlands, pp. 291-316.

Finke, M.D., 2002. Complete nutrient composition of commercially raised invertebrates used as food for insectivores. Zoo Biology 21: 269-285. https://doi.org/10.1002/zoo.10031
Gärdenfors, U. (ed.), 2010. The 2010 red list of Swedish species. ArtDatabanken, SLU, Uppsala, Sweden.

Halloran, A., Hanboonsong, Y., Roos, N. and Bruun, S., 2017. Life cycle assessment of cricket farming in north-eastern Thailand. Journal of Cleaner Production 156: 83-94.

Jones, B.A., Hatfield, R.D. and Muck, R.E., 1995. Screening legume forages for soluble phenols, polyphenol oxidase and extract browning. Journal of the Science of Food and Agriculture 67: 109112. https://doi.org/10.1002/jsfa.2740670117

Lee, M.R.F., Tweed, J.K.S., Minchin, F.R. and Winters, A.L., 2009. Red clover polyphenol oxidase: activation, activity and efficacy under grazing. Animal Feed Science and Technology 149: 250-264. https:// doi.org/10.1016/j.anifeedsci.2008.06.013

Lundy, M.E. and Parrella, M.P., 2015. Crickets are not a free lunch: protein capture from scalable organic side-streams via high-density populations of Acheta domesticus. PLoS ONE 10: e0118785.

Makkar, H.P.S., Tran, G., Heuzé, V. and Ankers, P., 2014. Stateof-the-art on use of insects as animal feed. Animal Feed Science and Technology 197: 1-33. https://doi.org/10.1016/j. anifeedsci.2014.07.008

McCluney, K.E. and Date, R.C., 2009. The effects of hydration on growth of the house cricket, Acheta domesticus. Journal of Insect Science 8: 32. https://doi.org/10.1673/031.008.3201

McDonald, P., 2011. Animal nutrition. Prentice Hall/Pearson, Harlow, UK.

McFarlane, J.E., 1964. The protein requirements of the house cricket, Acheta Domesticus L. Canadian Journal of Zoology 42: 645-647. https://doi.org/10.1139/z64-055

Mertens, D.R., Allen, M., Carmany, J., Clegg, J., Davidowicz, A., Drouches, M., Frank, K., Gambin, D., Garkie, M., Gildemeister, B., Jeffress, D., Jeon, C.S., Jones, D., Kaplan, D., Kim, G.N., Kobata, S., Main, D., Moua, X., Paul, B., Robertson, J., Taysom, D., Thiex, N., Williams, J. and Wolf, M., 2002. Gravimetric determination of amylase-treated neutral detergent fiber in feeds with refluxing in beakers or crucibles: collaborative study. Journal of AOAC International 85: 1217-1240.

Miech, P., Berggren, Å., Lindberg, J.E., Chhay, T., Khieu, B. and Jansson, A., 2016. Growth and survival of reared Cambodian field crickets (Teleogryllus testaceus) fed weeds, agricultural and food industry by-products. Journal of Insects as Food and Feed 2: 285-292. https:// doi.org/10.3920/jiff2016.0028

Morales-Ramos, J.A., Rojas, M.G. and Dossey, A.T., 2018. Agedependent food utilisation of Acheta domesticus (Orthoptera: Gryllidae) in small groups at two temperatures. Journal of Insects as Food and Feed 4: 51-60. https://doi.org/10.3920/jiff2017.0062

Nakagaki, B.J. and Defoliart, G.R., 1991. Comparison of diets for massrearing Acheta domesticus (Orthoptera: Gryllidae) as a novelty food, and comparison of food conversion efficiency with values reported for livestock. Journal of Economic Entomology 84: 891-896. https:// doi.org/10.1093/jee/84.3.891

National Research Council (NRC), 1998. Nutrient requirements of swine, $10^{\text {th }}$ revised edition. National Academic Press, Washington, DC, USA. 
Nielsen, B.L., De Jong, I.C. and De Vries, T.J., 2016. The use of feeding behaviour in the assessment of animal welfare BT - nutrition and the welfare of farm animals. In: Phillips, C.J.C. (ed.) Springer International Publishing, Cham, Switzerland, pp. 59-84. https:// doi.org/10.1007/978-3-319-27356-3_4

Nordic Committee on Food Analysis, 1979. Nitrogen. Determination in food and feed according to Kjeldahl. Report no. 6. Nordic Committee on Food Analysis, Uppsala, Sweden.

Oonincx, D.G.A.B., Van Broekhoven, S., Van Huis, A. and Van Loon, J.J.A., 2015. Feed conversion, survival and development, and composition of four insect species on diets composed of food by-products. PLoS ONE 14: e222043. https://doi.org/10.1371/ journal.pone.0144601

Oonincx, D.G.A.B., Van Itterbeeck, J., Heetkamp, M.J.W., Van den Brand, H., Van Loon, J.J.A. and Van Huis, A., 2010. An exploration on greenhouse gas and ammonia production by insect species suitable for animal or human consumption. PLoS ONE 5: e14445. https://doi.org/10.1371/journal.pone.0014445

Orinda, M.A., 2018. Effects of housing and feed on growth and efficiency of production of Acheta domesticus (L) and Gryllus bimaculatus for sustainable commercial cricket production in the Lake Victoria region, Kenya. PhD thesis, School of Agricultural and Food Sciences, Jaramogi Oginga Odinga University of Science and Technology, Bondo, Kenya.

Pahlow, G., Muck, R.E., Driehuis, F., Elferink, S.J.W.H.O. and Spoelstra, S.F., 2003. Microbiology of ensiling. In: Buxton, D.R., Muck, R.E. and Harrison, J.H. (ed.) Silage science and technology. Agronomy monograph 42. American Society of Agronomy, Crop Science Society of America, Soil Science Society of America, Madison, WI, USA, pp. 31-93. https://doi.org/10.2134/agronmonogr42.c2

Patton, R.L., 1978. Growth and development parameters for Acheta domesticus. Annals of the Entomological Society of America 71: 40-42. https://doi.org/10.1093/aesa/71.1.40

Purwin, C., Fijałkowska, M., Lipiński, K., Wierzbowska, J., Kobzhassarov, T.Z. and Michalski, J., 2015. Changes in the amino acid composition during the ensiling of lucerne and red clover in round bales. Journal of Elementology 20: 965-973. https://doi. org/10.5601/jelem.2015.20.1.863

Roe, R.M., Clifford, C.W. and Woodring, J.P., 1980. The effect of temperature on feeding, growth, and metabolism during the last larval stadium of the female house cricket, Acheta domesticus. Journal of Insect Physiology 26: 639-644. https://doi. org/10.1016/0022-1910(80)90034-7

Rooke, J.A. and Hatfield, R.D., 2003. Biochemistry of ensiling. In: Buxton, D.R., Muck, R.E. and Harrison, J.H. (ed.) Silage science and technology. Agronomy Monograph 42. American Society of Agronomy, Crop Science Society of America, Soil Science Society of America, Madison, WI, USA, pp. 95-139. https://doi.org/10.2134/ agronmonogr42.c3

Sheldrick, R., Thomson, D. and Newman, G., 1987. Legumes for milk and meat. Chalcombe Publications, Marlow, UK.
Simpson, S.J., Sword, G.A., Lorch, P.D. and Couzin, I.D., 2006. Cannibal crickets on a forced march for protein and salt. Proceedings of the National Academy of Sciences 103: 4152-4156. https://doi. org/10.1073/pnas.0508915103

Smil, V., 2002. Worldwide transformation of diets, burdens of meat production and opportunities for novel food proteins. Enzyme and Microbial Technology 30: 305-311. https://doi.org/10.1016/ S0141-0229(01)00504-X

Tacon, A.G.J. and Metian, M., 2008. Global overview on the use of fish meal and fish oil in industrially compounded aquafeeds: trends and future prospects. Aquaculture 285: 146-158. https:// doi.org/10.1016/j.aquaculture.2008.08.015

Tyree, W.A., Pfander, W.H. and Stone, P.C., 1976. Response of crickets to amount of forage in the diet. Journal of Dairy Science 59: 164-166. https://doi.org/10.3168/jds.s0022-0302(76)84172-0

Vaga, M., Gustafsson, E. and Jansson, A., 2018. Evaluation of reusable hiding units for rearing house crickets (Acheta domesticus). In: EAAP (ed.) Book of abstracts of the $69^{\text {th }}$ annual meeting of the European federation of animal science, August 27-31, 2018, Dubrovnik, Croatia. Wageningen Academic Publishers, the Netherlands, pp. 470.

Van Huis, A., Van Itterbeeck, J., Klunder, H., Mertens, E., Halloran, A., Muir, G. and Vantomme, P., 2013. Edible insects: future prospects for food and feed security. FAO Forestry Paper no. 171. Food and Agriculture Organization of the United Nations (FAO), Rome, Italy, 187 pp. Available at: http://www.fao.org/docrep/018/i3253e/ i3253e.pdf.

Wiersma, D.W., Smith, R.R., Mlynarek, M.J., Rand, R.E., Sharpee, D.K. and Undersander, D.J., 1998. Harvest management effects on red clover forage yield, quality, and persistence. Journal of Production Agriculture 11: 309-313.

Wilkinson, J.M., 2011. Re-defining efficiency of feed use by livestock. Animal 5: 1014-1022. https://doi.org/10.1017/s175173111100005x Williams, C.L., Tabler, G.T. and Watkins, S.E., 2013. Comparison of broiler flock daily water consumption and water-to-feed ratios for flocks grown in 1991, 2000-2001, and 2010-2011. Journal of Applied Poultry Research 22: 934-941. https://doi.org/10.3382/ japr.2013-00767

Wilsie, C.P. and Hollowell, E.A., 1948. Effect of time of cutting red clover on forage yields, seed setting and chemical composition. Iowa Agriculture and Home Economics Experiment Station. Research Bulletin 28: 357. https://ib.dr.iastate.edu/researchbulletin/vol28/ iss357/1

Woodring, J.P., Roe, R.M. and Clifford, C.W., 1977. Relation of feeding, growth, and metabolism to age in the larval, female house cricket. Journal of Insect Physiology 23: 207-212. https:// doi.org/10.1016/0022-1910(77)90031-2

World Health Organization (WHO), 2007. Protein and amino acid requirements in human nutrition report of a joint WHO/FAO/ UNU expert consultation. WHO Technical Report Series No. 935. WHO, Geneva, Switzerland. 
